\title{
PENGARUH STRATEGI PEMBELAJARAN KOOPERATIF DAN MOTIVASI BELAJAR TERHADAP HASIL BELAJAR DETEKSI DINI TUMBUH KEMBANG AUD
}

\author{
Meriyati \\ e-mail: meriyati.yati@yahoo.com \\ Fakultas Tarbiyah dan Keguruan, Institut Agama Islam Negeri Raden Intan Lampung
}

\begin{abstract}
Abstrak:Tujuan dari penelitian ini adalah mempelajari pengaruh strategi pembelajaran kooperatif dan motivasi belajar terhadap hasil belajar Deteksi Dini Tumbuh Kembang AUD pada mahasiswa. Penelitian dilakukan di IAIN Raden Intan Lampung dengan sampel sebanyak 40 mahasiswa diseleksi secara acak. Penelitian ini dilakukan pada bulan April sampai dengan Agustus 2013. Penelitian ini merupakan penelitian eksperimen didesain dengan treatment by level $2 \times 2$. Hasil penelitian ini adalah sebagai berikut: (1) hasil belajar mahasiswa dengan strategi kooperatif lebih tinggi daripada mahasiswa dengan strategi ekspositori, (2) adanya pengaruh interaksi antara strategi pembelajaran dan motivasi belajar terhadap hasil belajar deteksi dini tumbuh kembang AUD, (3) mahasiswa dengan motivasi belajar tinggi memperoleh hasil belajar lebih tinggi bila digunakan strategi pembelajaran kooperatif dibandingkan dengan bila digunakan strategi ekspositori, dan (4) hasil belajar pada mahasiswa deteksi dini tumbuh kembang AUD dengan motivasi belajar yang rendah, lebih tinggi bila digunakan strategi ekspositori. Kesimpulan dari hasil penelitian ini, hasil belajar mahasiswa mata kuliah deteksi dini tumbuh kembang AUD dapat ditingkatkan dengan strategi pembelajaran yang sesuai dengan tingkat motivasi belajarnya.
\end{abstract}

Kata kunci: kooperatif, ekspositori, motivasi belajar

\section{EFFECT OF COOPERATIVE INSTRUCTIONAL STRATEGY AND LEARNING MOTIVATION TO LEARNING OUTCOME OF THE EARLY DETECTION GROWING CHILDHOOD}

\begin{abstract}
The objective of this research is to study the effect of instructional strategy of cooperative and learning motivation on the learning outcome in the course of Early Detection of Early Aged Children's Development. The research conducted conducted at IAIN Raden Intan Lampung as from April through August 2013, selected 40 students randomly as samples. The research employed experimental research with treatment by level $2 \times 2$. The findings indicate (1) learning outcomes of the students with cooperative instructional strategy is higher than those who received expository instructional strategy,(2) there is interaction between instructional strategy and learning motivation of the students, (3) learning outcomes of the students with high learning motivation are higher when cooperative instructional strategy is used than when they learn with expository instructional strategy, and (4) learning outcomes of the students with low learning motivation are higher when cooperative instructional strategy is used than when they learn with expository instructional strategy. Result of the research shows that students'learning outcomes on early detection of development kindergarten could be improved by applying appropriate teaching instructional strategy considering their learning motivation level.
\end{abstract}

Keywords :cooperative, expository, learning motivation, learning outcome.

\section{PENDAHULUAN}

Salah satu faktor penyebab rendahnya kualitas pendidikan adalah kualitas pembelajaran. Peningkatan kualitas pembelajaran diawali dengan merancang pembelajaran, pembelajaran yang dirancang dengan baik dan memperhatikan kondisi, memilih strategi yang tepat akan meningkatkan kualitas belajar dan dengan sendirinya akan meningkatkan hasil belajar.

Strategi pembelajaran meliputi berbagai aspek dalam memilih suatu sistem pelaksanaan, mengurutkan dan mengelompokkan isi pembelajaran, menjelaskan komponen-komponen belajar yang akan dimasukkan dalam pembelajaran, menentukan cara 
mengelompokkan peserta didik selama pembelajaran, membuat struktur pembelajaran dan memilih media untuk melaksanakan pembelajaran (Dick \& Carey,2009: 178). Terdapat tiga kegiatan pokok dalam strategi pembelajaran menurut pengertian tersebut yaitu pemilihan media pembelajaran, pengurutan materi pembelajaran dan komponen yang berkaitan dengan pembelajaran.

Beberapa hal yang harus dipertimbangan dalam pemilihan strategi pembelajaran adalah: pertama, seberapa jauh strategi yang disusun itu didukung dengan teori-teori psikologi dan teori pembelajaran yang ada. Kedua, seberapa jauh strategi disusun secara tepat dalam membuat siswa mencapai tujuan pembelajaran yang telah ditetapkan sebelumnya (Mukhtar dan Iskandar, 2012: 187-188).

Kompetensi yang diharapkan dari mata kuliah deteksi dini tumbuh kembang AUD agar dapat membekali calon guru melaksanakan tugas sebagai seorang guru dalam proses pembelajaran secara lebih efektif. Agar pembelajaran lebih berkualitas dituntut keterlibatan mahasiswa secara intensif dalam proses pembelajaran. Keterlibatan dari mahasiswa dapat dilihat dari partisipasi aktif mereka dalam proses pembelajaran. Keterlibatan tersebut dilandasi motivasi dan minat yang tinggi dari mahasiswa. Dosen pengampu mata kuliah deteksi dini tumbuh kembang AUD, di samping menguasai pengetahuan yang luas dan mendalam tentang materi perkuliahan, juga dituntut menguasai penggunaan berbagai macam strategi pembelajaran yang dapat membangkitkan minat dan motivasi mahasiswa dalam proses pembelajaran.

Mahasiswa pada proses pembelajaran tidak sekedar menghafal konsep dasar dalam mata kuliah deteksi dini tumbuh kembang AUD tetapi melatih mereka untuk meningkatkan pemahaman, daya nalar dan daya analisisnya. Dengan kata lain, diperlukan strategi yang pada dasarnya memberikan lebih banyak kesempatan untuk berinisiatif dari pada sekedar mendengarkan atau menerima informasi.

Salah satu strategi yang dapat diterapkan adalah: strategi kooperatif merupakan strategi pembelajaran yang dirancang untuk mendidik kerjasama kelompok dan interaksinya. Strategi ini dirancang menyingkirkan persaingan yang terdapat di dalam kelas yang cendrung menimbulkan pihak yang menang dan yang kala. Strategi kooperatif dirancang untuk mendorong siswa bekerjasama dan saling membantu satu sama lain untuk mempelajari tujuan-tujuan umumnya (Jacobsen, Eggen and Kauchak, 2009: 230)

Pelaksanaan strategi kooperatif didasari atas falsafah bahwa manusia adalah makhluk sosial tidak ada seorangpun yang dapat hidup sendiri tanpa bantuan dan kerjasama dengan orang lain. Metode kooperatif dapat dilakukan melalui diskusi

Pada situasi pembelajaran kooperatif, peran dosen sebagai ahli akademis dan pengelola kelas untuk meningkatkan efektivitas fungsi kelompok. Penerapan strategi kooperatif dapat meningkatkan dan mengembangkan pemikiran yang kritis dan kreatif, meningkatkan harga diri, kesadaran sosial serta toleransi antar individu yang beragam (Holt, 2004: 1)

Dalam menerapkan strategi kooperatif ada lima unsur yang dapat diterapkan yaitu : (1) saling ketergantungan positif, (2) tanggung jawab perseorangan, (3) tatap muka, (4) komunikasi antar anggota dan (5) evaluasi proses kelompok (Lie, 2002 : 31)

Penelitian yang dilakukan oleh Sofyan di Sekolah Menengah Kejuruan (SMK) pada mata pelajaran motor otomotif, menyimpulkan bahwa strategi pembelajaran kooperatif lebih efektif dalam meningkatkan hasil belajar dibandingkan dengan strategi pembelajaran konvensional (Sofyan, 2002: 18)

Sejalan dengan penelitian yang dilakukan oleh Sofyan, penelitian yang berkenaan dengan strategi kooperatif dilakukan oleh Mursidah, hasil penelitian menyimpulkan bahwa, strategi pembelajaran kooperatif lebih efektif dalam meningkatkan hasil belajar matematika siswa yang memiliki motivasi berprestasi tinggi, sedangkan strategi pembelajaran konvensional lebih efektif dalam meningkatkan hasil belajar matematika siswa yang memiliki motivasi berprestasi rendah (Mursidah, 2002: 114-115)

Penelitian dilakukan di Amerika oleh Slavin, menyimpulkan bahwa dibanding strategi pembelajaran kompetitif dan individual, siswa yang belajar dengan strategi kooperatif lebih termotivasi untuk belajar guna mencapai tujuan belajar secara bersama (Slavin, 1995: 21)

Strategi kooperatif berbeda dengan strategi ekspositori. Pada strategi ekspositori,guru menyajikan bahan dalam bentuk yang telah dipersiapkan secara rapi, sistematik dan lengkap sehingga siswa tingggal menyimak dan mencernanya (Makmun, 2011: 233). Sedangkan pada kooperatif, dosen hanya sebagai motivator, fasilitator dan penekanan pembelajaran pada mahasiswanya (student centered).

Tujuan utama dari strategi pembelajaran ekspositori adalah memindahkan pengetahuan, keterampilan dan nilai-nilai kepada siswa (Dimyati dan Mudjiono, 2006: 172). Salah satu faktor penting yang harus diperhatikan oleh dosen dalam menerapkan strategi pembelajaran kooperatif ialah faktor motivasi belajar mahasiswa. Motivasi belajar adalah merupakan daya penggerak psikis dari dalam diri seseorang untuk 
dapat melakukan kegiatan belajar dan menambah keterampilan, pengalaman. Motivasi mendorong dan mengarah minat belajar untuk tercapai suatu tujuan (Yamin, 2012: 113)

Motivasi belajar adalah keseluruhan daya penggerak psikis di dalam diri seseorang yang menimbulkan kegiatan belajar dan memberikan arahan pada kegiatan belajar untuk mencapai suatu tujuan (Winkel, 2003: 87) Jadi motivasi belajar memegang peranan penting dalam memberikan dorongan kepada seseorang untuk melakukan kegiatan belajar dengan arah yang jelas

Masalah dalam penelitian ini dibatasi pada; (1) pengaruh penerapan strategi pembelajaran kooperatif dan strategi pembelajaran ekspositori sebagai variabel bebas (2) pengaruh motivasi belajar mahasiswa yang dibedakan tinggi dan rendah sebagai variabel atribut (3) pengaruh interaksi antara strategi pembelajaran dan motivasi belajar terhadap hasil belajar mahasiswa.

Penelitian ini bertujuan untuk memperoleh gambaran pengaruh penerapan strategi pembelajaran kooperatif dan strategi pembelajaran ekspositori terhadap hasil belajar deteksi dini tumbuh kembang AUD.Pengaruh motivasi belajaryang dibedakan tinggi dan rendah terhadap hasil belajar deteksi dini tumbuh kembang AUD. Pengaruh interaksi antara strategi pembelajaran dan motivasi belajar terhadap hasil belajar mahasiswa.

\section{METODE PENELITIAN}

Metode yang digunakan dalam penelitian ini adalah metode eksperimen dengan rancangan treatment by level $2 \times 2$ sebagai variabel terikat dalam penelitian ini adalah hasil belajar deteksi dini tumbuh kembang AUD. Variabel bebas pertama sebagai perlakuan adalah strategi pembelajaran yang dibedakan pada strategi pembelajaran kooperatif dan strategi ekspositori sebagai variabel kontrol. sebagai variabel atribut adalah motivasi belajar yang dibedakan pada motivasi belajar tinggi dan rendah. Pengaruh variabel bebas terhadap variabel terikat disebut sebagai pengaruh interaksi yang konstalasinya dapat dilihat melalui tabel 1.

Tabel 1. Desain Treatment by Level $2 \times 2$

\begin{tabular}{|c|c|c|}
\hline \multirow{2}{*}{$\begin{array}{c}\text { Motivasi } \\
\text { Belajar (B) }\end{array}$} & \multicolumn{2}{|c|}{ Strategi Pembelajaran } \\
\cline { 2 - 3 } & $\begin{array}{c}\text { kooperatif } \\
\text { (A1) }\end{array}$ & $\begin{array}{c}\text { Ekspositori } \\
\text { (A2) }\end{array}$ \\
\hline Tinggi (B1) & A1B1 & A2B1 \\
\hline Rendah (B2) & A1B2 & A2B2 \\
\hline
\end{tabular}

Data diperoleh dengan cara melakukan tes materi deteksi dini tumbuh kembang AUD kepada mahasiswa semester IV Jurusan Pendidikan Guru Raudhatul Athfal (PGRA) pada akhir eksperimen. Kegiatan penelitian ini dilakukan selama 6 bulan dengan masa uji antara bulan Februari sampai dengan Juli 2013. Sebelum data dianalisis, dilakukan uji prasyarat analisis dengan menguji normalitas dan homogenitas data.Uji normalitas menggunakan uji Lilliefors, sedang uji homogenitas menggunakan uji analisis Bartlett.

Penelitian ini merupakan penelitian eksperimen dengan rancangan factorial 2 x 2.Analisi data menggunakan ANAVA dua jalur, apabila hasil uji menunjukkan adanya interaksi maka dilanjutkan dengan uji Tukey untuk melihat efek sederhana mana yang lebih unggul, bila terjadi efek sederhana yang berlawanan maka disimpulkan terjadi interaksi.

\section{HASIL DAN PEMBAHASAN}

Dari perhitungan yang dilakukan terhadap hasil belajar deteksi dini tumbuh kembang AUDmahasiswa seperti terlihat pada tabel 2, pada kelompok mahasiswa yang diterapkan pembelajaran dengan strategi kooperatif, diperoleh $\mathrm{n}=20$ dengan skor rata-rata $=$ 38,45; standar deviasi $=5,99$.

Sedang perhitungan yang dilakukan terhadap hasil belajar deteksi dini tumbuh kembang AUD mahasiswa pada kelompok yang dterapkan pembelajaran dengan strategi ekspositori, diperoleh $n=20$ dengan skor rata-rata $=36,40$. Nilai standar deviasi $=2,98$. Hasil belajar deteksi dini tumbuh kembang AUD pada kelompok mahasiswa dengan motivasi belajar tinggi, yang diterapkan pembelajaran dengan strategi kooperatif, diperoleh $n=10$ dengan skor rata-rata $=43,80$. Nilai standar deviasi $=1,32$.

Dan perhitungan terhadap hasil belajar deteksi dini tumbuh kembang AUD pada kelompok mahasiswa dengan motivasi rendah yang diterapkan pembelajaran dengan strategi ekspositori diperoleh $n=10$ dengan skor rata-rata $=33,10$; standar deviasi $=3,11$. Ringkasan hasil penelitian ini dapat dilihat pada tabel 2. 
Tabel 2. Ringkasan Data Hasil penelitian

\begin{tabular}{|c|l|l|l|l|}
\hline $\begin{array}{c}\text { Mo- } \\
\text { tivasi } \\
\text { Belajar } \\
\text { (B) }\end{array}$ & \multicolumn{4}{|c|}{ Strategi Pembelajaran (A) } \\
\cline { 2 - 5 } & \multicolumn{2}{|c|}{ Kooperatif (A1) } & \multicolumn{2}{c|}{ Ekspositori (A2) } \\
\hline \multirow{4}{*}{$\begin{array}{c}\text { Tinggi } \\
\text { (B1) }\end{array}$} & $\mathrm{n}=10$ & $\mathrm{Me}=44,25$ & $\mathrm{n}=10$ & $\mathrm{Me}=33,70$ \\
\cline { 2 - 5 } & $\mathrm{Xt}=46$ & $\mathrm{Mo}=$ & $\mathrm{Xt}=37$ & $\mathrm{Mo}=$ \\
& 44,25 & & 34,79 \\
\cline { 2 - 5 } & $\mathrm{Xr}=42$ & $\mathrm{SD}=1.32$ & $\mathrm{Xr}=27$ & $\mathrm{SD}=3,11$ \\
\cline { 2 - 5 } & $\overline{\mathrm{X}}=43,80$ & & $\mathrm{X}=33,10$ & \\
\hline \multirow{4}{*}{$\begin{array}{c}\text { Rendah } \\
\text { (B2) }\end{array}$} & $\mathrm{n}=10$ & $\mathrm{Me}=33,00$ & $\mathrm{n}=10$ & $\mathrm{Me}=39,83$ \\
\cline { 2 - 5 } & $\mathrm{Xt}=38$ & $\mathrm{Mo}=1,32$ & $\mathrm{Xt}=44$ & $\mathrm{Mo}=39,17$ \\
\cline { 2 - 5 } & $\mathrm{Xr}=27$ & $\mathrm{SD}=1,32$ & $\mathrm{Xr}=35$ & $\mathrm{SD}=2,98$ \\
\cline { 2 - 5 } & $\overline{\mathrm{X}}=33,10$ & & $\overline{\mathrm{X}}=39,70$ & \\
\hline \multirow{4}{*}{\begin{tabular}{l} 
Jumlah \\
\cline { 2 - 5 }
\end{tabular}} & $\mathrm{N}=20$ & $\mathrm{Me}=40,50$ & $\mathrm{~N}=20$ & $\mathrm{Me}=35,50$ \\
\cline { 2 - 5 } & $\mathrm{Xt}=46$ & $\mathrm{Mo}=$ & $\mathrm{Xt}=44$ & $\mathrm{Mo}=$ \\
\cline { 2 - 5 } & $\mathrm{Xr}=27$ & $\mathrm{SD}=5,99$ & $\mathrm{Xr}=27$ & $\mathrm{SD}=2,98$ \\
\cline { 2 - 5 } & & & $\overline{\mathrm{X}}=36,40$ & \\
\hline
\end{tabular}

Data di atas diuji dengan analisis variansi dengan menguji pengaruh antar kolom, antar baris dan interaksi antara baris dan kolom. Hasil perhitungan analisis varians (ANAVA) dua jalur yang menggambarkan hasil belajar deteksi dini tumbuh kembang AUD pada kelompok-kelompok data hasilnya dapat dilihat melalui tabel 3 sebagai berikut:

Tabel 3. Rangkuman Hasil Uji Anova Dua Arah

\begin{tabular}{|c|c|c|c|c|c|c|}
\hline \multirow{2}{*}{$\begin{array}{c}\text { Sum- } \\
\text { ber } \\
\text { Vari- } \\
\text { ans }\end{array}$} & \multirow[b]{2}{*}{$\mathrm{db}$} & \multirow[b]{2}{*}{ Jk } & \multirow{2}{*}{$\begin{array}{c}\text { RK } \\
=\underset{\mathrm{dK}}{\mathrm{JK}} / \\
\end{array}$} & \multirow[b]{2}{*}{$\begin{array}{c}\mathrm{Fh}=\mathrm{RK} / \\
\mathrm{RKD}\end{array}$} & \multicolumn{2}{|c|}{$F_{\text {tabel }}$} \\
\hline & & & & & 0,05 & 0,01 \\
\hline \multirow{3}{*}{$\begin{array}{l}\text { Strategi } \\
\text { Pembe- } \\
\text { lajaran } \\
\text { (A) } \\
\text { Motivasi } \\
\text { Belajar } \\
\text { (B) } \\
\text { Faktor } \\
\text { interaksi } \\
\text { (AxB) }\end{array}$} & 1 & 42,03 & 42,03 & $5,49^{*}$ & 4,11 & 7,39 \\
\hline & 1 & 42,03 & 42,03 & $5,49^{*}$ & - & - \\
\hline & 1 & 784,22 & 784,22 & $97,77^{*}$ & - & $\begin{array}{ll}- & - \\
-1\end{array}$ \\
\hline $\begin{array}{l}\text { Dalam } \\
\text { (D) }\end{array}$ & 36 & 275,50 & 7,65 & - & & \\
\hline $\begin{array}{l}\text { Total } \\
\text { dikore- } \\
\text { ksi (T) }\end{array}$ & 39 & 1107,78 & & - & & \\
\hline
\end{tabular}

Tabel 3 menghasilkan tiga hasil analisis variansi, variansi baris (A1A2), variansi kolom (B1B2), dan interaksi antara baris (A) dan kolom (B). Pada analisis variansi baris antara kelompok yang diterapkan pembelajaran dengan strategi kooperatif (A1) dan kelompok yang diterapkan pembelajaran dengan strategi ekspositori (A2) terhadap hasil belajar de- teksi dini tumbuh kembang AUDmenunjukkan nilai $\mathrm{F}_{\text {hit }}=5,49$ lebih besar dari Ftab pada taraf signifikansi alfa $\alpha(0.05)=4,11$, dan lebih besar dari nilai Ftab pada taraf signifikansi $\alpha(0,01)=7,39$. Hal ini berarti, terdapat perbedaan hasil belajar deteksi dini tumbuh kembang AUD yang signifikan antara kelompok $A 1$ dengan kelompok A2. Dengan demikian, hipotesis yang menyatakan bahwa hasil belajar deteksi dini tumbuh kembang AUDkelompok yang diterapkan pembelajaran strategi kooperatiflebih tinggi daripada hasil belajar deteksi dini tumbuh kembang AUD kelompok yang diterapkan pembelajaran strategi ekspositori adalah terbukti benar.

Hasil uji ANAVA dua jalur pada uji interaksi antara baris $(A)$ dan kolom (B) menunjukkan adanya pengaruh interaksi antara strategi pembelajaran kooperatif dan motivasi belajar terhadap hasil belajar deteksi dini tumbuh kembang AUD. Kesimpulan ini didapatkan setelah diperoleh $\mathrm{F}_{\text {hit }}=97,77$ lebih besar dari nilai $F_{\text {tab }}$ pada taraf signifikansi $\alpha(0,05)=4,11$ dan nilai $F_{\text {tab }}$ pada taraf signifikansi $\alpha(0,01)=7,39$. Ini berarti bahwa, hipotesis yang menyatakan bahwa terdapat interaksi antara strategi pembelajaran dengan motivasi belajar terhadap hasil belajar deteksi dini tumbuh kembang AUD adalah terbukti benar.

Untuk pengujian lebih lanjut dari hasil analisi varians digunakan Uji-Tukey. Rangkuman hasil uji Tukey dapat dilihat pada tabel berikut:

Tabel 4. Rangkuman Hasil Uji Tukey

\begin{tabular}{|c|c|c|c|}
\hline \multirow{2}{*}{ No. } & \multirow{2}{*}{ Kelompok } & \multirow{2}{*}{$\mathbf{Q}_{\text {hitung }}$} & $\mathbf{Q}_{\text {tabel }}$ \\
\cline { 4 - 4 } & & $\mathbf{a}=\mathbf{0 , 0 5}$ \\
\hline 1 & A1 dengan B1 & 12,23 & 3,15 \\
\hline 2 & A2 dengan B2 & 7,54 & 3,15 \\
\hline 3 & A1 dengan A2 & 2,95 & 3,15 \\
\hline
\end{tabular}

Selanjutnya hasil uji Tukey pada kelompok motivasi tinggi (B1), antara yang diterapkan pembelajaran strategi kooperatif (A1B1) dan yang diterapkan pembelajaran dengan strategi ekspositori (A2B1)

Berdasarkan tabel 4, diperoleh $Q_{\text {hit }}=12,23$ lebih besar dari $Q_{\text {tab }}$ pada taraf signifikansi $\alpha(0,05)=3,15$. Dengan demikian $\mathrm{HO}$ ditolak pada taraf nyata 0,05 $(12,23>3,15)$. Kesimpulannya, pengaruh pe-ningkatan hasil belajar deteksi dini tumbuh kembang AUD pada kelompok motivasi belajar tinggi (B1), yang diterapkan pembelajaran dengan strategi kooperatif (A1B1) lebih tinggi dari kelompok mahasiswa yang diterapkan pembelajaran dengan strategi ekspositori (A2B1). Dengan demikian, hipotesis yang menyatakan bahwa pengaruh peningkatan hasil belajar deteksi dini tumbuh 
kembang AUD pada kelompok motivasi tinggi yang diterapkan pembelajaran dengan strategi kooperatif lebih tinggi dari yang diterapkan pembelajaran dengan strategi ekspositori adalah terbukti benar.

Sementara, pada kelompok motivasi belajar rendah (B2), perbandingan pengaruh peningkatan hasil belajardeteksi dini tumbuh kembang AUD antara kelompok yang diterapkan pembelajaran dengan strategi kooperatif (A1B2) dan kelompok yang diterapkan pembelajaran dengan strategi ekspositori (A2B2), menunjukkan bahwa $Q_{\text {hit }}=7,54$ lebih kecil dari $Q_{\text {tab }}$ pada taraf signifikansi $\alpha(0,05)=3,15$. Dengan demikian $\mathrm{H}_{0}$ diterima pada taraf nyata $0,05(7,54<$ $3,15)$. Kesimpulannya, pengaruh peningkatan hasil belajar deteksi dini tumbuh kembang AUD pada kelompok mahasiswa dengan motivasi belajar rendah yang diterapkan pembelajaran dengan strategi kooperatif (A1B2) lebih rendah dari hasil belajar deteksi dini tumbuh kembang AUD kelompok mahasiswa yang diterapkan pembelajaran dengan strategi ekspositori (A2B2). Dengan demikian, hipotesis yang menyatakan bahwa pengaruh peningkatan hasil belajar deteksi dini tumbuh kembang AUD pada kelompok motivasi belajar rendah yang diterapkan pembelajaran dengan strategi kooperatif lebih rendah dari yang diterapkan pembelajaran dengan strategi ekspositori juga terbukti benar.

Dengan demikian, dapat disimpulkan bahwa: (1) pengaruh kelompok yang diterapkan pembelajaran dengan strategi kooperatif menunjukkan hasil belajar deteksi dini tumbuh kembang AUD lebih tinggi daripada kelompok yang diterapkan pembelajaran dengan strategi ekspositori, (2) pengaruh pada kelompok motivasi belajar tinggi, hasil belajar deteksi dini tumbuh kembang AUD pada mahasiswa yang diterapkan pembelajaran dengan strategi kooperatif lebih tinggi daripada kelompok yang diterapkan pembelajaran dengan strategi ekspositori, (3) pengaruh pada kelompok motivasi belajar rendah, hasil belajar deteksi dini tumbuh kembang AUD mahasiswa yang diterapkan pembelajaran dengan strategi kooperatif lebih rendah dari kelompok yang diterapkan pembelajaran dengan strategi ekspositori dan (4) terdapat pengaruh interaksi antara strategi pembelajaran dan motivasi belajar terhadap hasil belajar deteksi dini tumbuh kembang AUD.

Hasil penelitian yang dideskripsikan pada bagian sebelumnya menunjukkan bahwa, pengaruh kelompok yang diterapkan pembelajaran dengan strategi kooperatif, menunjukkan hasil belajar deteksi dini tumbuh kembang AUD lebih tinggi daripada kelompok yang diterapkan pembelajaran dengan strategi ekspositori.Hasil penelitian ini diperkuat oleh hasil penelitian yang dilakukan oleh Slavin, menyimpulkan bahwa siswa yang belajar dengan strategi kooperatif lebih termotivasi untuk belajar guna mencapai tujuan belajar secara bersama dibandingkan dengan strategi pembelajaran kompetitif individual.

Pengaruh hasil belajar deteksi dini tumbuh kembang AUD mahasiswa yang memiliki motivasi belajar tinggi yang mendapatkan strategi pembelajaran kooperatif dan yang mendapatkan strategi pembelajaran ekspositori. Rerata skor hasil belajar mahasiswa yang memiliki motivasi belajar tinggi yang dibelajarkan menggunakan strategi pembelajaran kooperatif lebih tinggi dari mahasiswa dibelajarkan dengan strategi ekspositori. Hasil penelitian ini diperkuat oleh hasil penelitian yang dilakukan oleh Mursidah, menyimpulkan bahwa strategi pembelajaran kooperatif lebih efektif dalam meningkatkan hasil belajar matematika siswa yang memiliki motivasi berprestasi tinggi, sedangkan strategi pembelajaran konvensional lebih efektif dalam meningkatkan hasil belajar matematika siswa yang memiliki motivasi berprestasi rendah

Pengaruh hasil belajar deteksi dini tumbuh kembang AUD mahasiswa yang memiliki motivasi belajar rendah yang mendapatkan strategi pembelajaran kooperatif dan yang mendapatkan strategi pembelajaran ekspositori Indikasi penelitian menunjukkan hasil belajar mahasiswa yang menggunakan strategi pembelajaran kooperatif lebih rendah dari hasil belajar psikologi pendidikan mahasiswa yang menggunakan strategi pembelajaran ekspositori.

Penerapan aktivitas belajar yang menggunakan strategi pembelajaran ekspositori, mahasiswa akan dihadapkan pada konsep-konsep tertentu yang harus dihafalkan, sehingga tidak menuntut mahasiswa untuk berfikir ulang dan setelah proses pembelajaran berakhir, siswa diharapkan dapat memahaminya dengan benar

Strategi ekspositori lebih dipengaruhi oleh teori belajar behavioristik. Menurut aliran behavioristik belajar pada hakekatnya adalah pembentukan asosiasi antara kesan yang ditangkap panca indra dengan kecendrungan untuk bertindak atau hubungan antara stimulus dan respon (S-R). Dalam implementasi strategi ekspositori, peran dosen sebagai pemberi stimulus merupakan faktor yang sangat penting dan lebih mendominasi. Pada mahasiswa yang memiliki motivasi belajar rendah, strategi pembelajaran ekspositori ini membuat mereka lebih nyaman, sehingga hasil belajar mahasiswa yang dibelajarkan dengan strategi pembelajaran ekspositori lebih tinggi dibandingkan dengan mahasiswa yang menggunakan strategi pembelajaran kooperatif. 
Pengaruh Interaksi antara strategi pembelajaran dan motivasi belajar terhadap hasil belajar deteksi dini tumbuh kembang AUD. Banyak hal yang diperhatikan dalam pembelajaran, selain pemilihan strategi pembelajaran juga hendaknya memperhatikan karakteristik mahasiswa diantaranya motivasi belajar mereka. Pemilihan strategi yang tepat bedampak pada hasil belajar yang efektif (tujuan pembelajaran tercapai).

Strategi kooperatif dapat diorganisasikan ke dalam kegiatan pembelajaran yang menekankan pada keaktifan mahasiswa (student center). Kegiatan ini yang membedakan dengan strategi pembelajaran ekspositori yang menitikberatkan penekanan kegiatan berpusat pada dosen (teacher center)

Mahasiswa yang telah terbiasa dengan proses pembelajaran yang berpusat pada mahasiswanya akan memberikan peran reseptif dan pasif, jika diterapkan dengan strategi kooperatif dan mereka akan lebih nyaman dengan strategi pembelajaran ekspositori. Hal tersebut mengidentifikasikan bahwa hasil belajar akan tercapai dengan baik bila disesuaikan dengan motivasi belajar yang dimiliki mahasiswa, dengan demikian hasil belajar deteksi dini tumbuh kembang AUD akan tercapai dengan baik apabila diterapkan strategi pembelajaran yang sesuai dengan motivasi belajar mahasiswa

Penelitian ini hanya mengkaji dari segi strategi pembelajaran dan motivasi belajar. Selain dari strategi kooperatif dan ekspositori masih banyak strategi lain dapat diterapkan dalam perkuliahan yang mempengaruhi hasil belajar deteksi dini tumbuh kembang AUD. Peneliti hanya melihat faktor motivasi belajar selain faktor tersebut ada variabel lainnya yang dapat mempengaruhi hasil belajar seperti gaya belajar, kemandirian dan lainnya yang dapat dikaji.

\section{PENUTUP}

\section{Kesimpulan}

Hasil analisis data menunjukkan bahwa secara keseluruhan efektivitas kelompok yang diterapkan pembelajaran dengan strategi kooperatif, menunjukkan hasil belajar deteksi dini tumbuh kembang AUD lebih tinggi daripada kelompok yang diterapkan pembelajaran dengan strategi ekspositori. Dari temuan ini dapat disimpulkan bahwa untuk meningkatkan hasil belajar deteksi dini tumbuh kembang AUD, dapat dilakukan dengan menggunakan strategi pembelajaran kooperatif.

Pada kelompok mahasiswa yang memiliki motivasi belajar tinggi, hasil belajar deteksi dini tumbuh kembang AUD mahasiswa yang mengikuti strategi pembelajaran kooperatif lebih tinggi daripada mahasiswa yang mengikuti strategi pembelajaran ekspositori. Dari temuan ini dapat disimpulkan bahwa untuk meningkatkan hasil belajar deteksi dini tumbuh kembang AUD mahasiswa yang memiliki motivasi belajar tinggi dapat dilakukan dengan menggunakan strategi pembelajaran dengan kooperatif.

Kelompok mahasiswa dengan motivasi rendah, hasil belajar deteksi dini tumbuh kembang AUD maha- siswa yang mengikuti strategi pembelajaran kooperatif lebih rendah daripada siswa yang mengikuti strategi pembelajaran ekspositori. Dari temuan ini dapat disimpulkan bahwa untuk meningkatkan hasil belajar deteksi dini tumbuh kembang AUD mahasiswa yang memiliki tingkat motivasibelajar rendah dapat dilakukan dengan menggunakan strategi pembelajaran Ekspositori.

Terdapat pengaruh interaksi antara strategi pembelajaran dan motivasi belajar terhadap hasil belajar deteksi dini tumbuh kembang AUD. Dari hasil penelitian disimpulkan bahwa untuk meningkatkan hasil belajar deteksi dini tumbuh kembang AUD bagi mahasiswa yang memiliki tingkat motivasi belajar tinggi dapat dilakukan dengan menggunakan strategi pembelajaran kooperatif, sebaliknya bagi mahasiswa yang memiliki motivasi belajar rendah dapat dilakukan dengan strategi pembelajaran Ekspositori. Pada akhirnya proses pembelajaran deteksi dini tumbuh kembang AUD diharapkan mampu menerapkan strategi pembelajaran kooperatif dan strategi pembelajaran ekspositori sesuai motivasi belajar yang dimiliki setiap mahasiswa dalam perkuliahan.

\section{DAFTAR PUSTAKA}

Dimyati dan mudjiono. (2006). Belajar dan pembelajaran, Jakarta: Rineka Cipta

Holt, John. (2004). Cooperative learning, http;volcano. und.nodak.edu/wwwdocs/msh/11c/is/cl.html

Jacobson, David dan Paul Eggen, Donald Kauchak,
Metodes for teaching a skills approach. Columbus: Ohio Merill Publishing Cmpany, 2005

Lie, Anita. (2002). ICooperative Learning, Mempraktekkan cooperatif learning di ruang-ruang kelas. Jakarta: Grasindo, 
Makmun, Abim Syamsudin. Psikologi kependidikan perangkat sistem pengajaran modul. Bandung : Remaja Rosda Karya, 2011

Mukhtar dan Iskandar. (2012). Desain pembelajaran berbasis tik, Jakarta: Referensi.

Mursidah, Syarifah. (2002). Pengaruh strategi pembelajaran dan motivasi berprestasi terhadap hasil belajar matematika, Jakarta: PPS UNJ.

Slavin, Robert E. (1995). Cooperative learning theory, research and practice, London: Allyn and bacon,
Sofyan, Herminarto. (2002). "Pengaruh pembelajaran dan gaya berfikir siswa terhadap hasil belajar motor otomotif",Disertasi, Jakarta: PPS,

Yamin, Martinis. (2012). Desain baru pembelajaran konstruktivistik, Jakarta : Refrensi.

Walter, Dick \& Lau Carrey. (2009). The systematical design of instruction, New York: Harper Collins College Publisher,

WS, Winkel. (2003). Psikologi pengajaran, Jakarta: Grasindo, 